Simon SLOKAN*, PhD

Ministry of the Interior of the Republic of Slovenia, Slovenia

DOI: $10.5937 /$ bezbednost $1803117 \mathrm{~S}$

UDK: 351.74:343.97:796.093(497.4)

Pregledni naučni rad Primljen: 5.9.2018. godine Revizija: 25.11.2018. godine Datum prihvatanja: 26.12.2018. godine

\title{
Prohibition of participation in sporting events and trip interruption - police powers in the Republic of Slovenia as means to reducing violence at sporting events
}

Summary: The purpose of this paper is to present police powers in Slovenia, with the focus on the powers which are directly aimed at reduce violence at sporting events. In recent years, both worldwide and in Slovenia, we have witnessed an increase in different forms of violence during various sporting events posing direct or indirect threat to overall security. Based on this scenario and based on various bylaws, Slovenia has adopted a series of measures aimed at preventing and suppressing various forms of violence at sporting events. In 2013, police officers were, among other things, awarded with two additional powers - the prohibition of participation in sporting events, and the trip cancellation and interruption.

This paper intends to present all the powers of the Slovenian police, with the emphasis on the police powers aimed at preventing violence at sporting events. It is also intended to display the number of imposed measures, and the number of detected violations of these powers. In addition, it presents qualitative method of data analysis and/or normative solutions, as well as other written materials relevant to the process of analysis. This also includes the quantitative method of statistical analysis, which displays the actual data.

The content itself is topical in the sense of the knowledge of police powers and the importance of awareness with regard to prevention of violence at sporting events.

*E-mail: sslokan@hotmail.com 
Key words: police, police powers, prohibition of participation in sporting events, trip cancellation and interruption, violence

\section{Preface}

Every day, in the context of various levels of social life, we witness events and activities that directly or indirectly affect the life of an individual or his/her human rights. One such aspect relates to activities of individuals and groups who, in the context of various sporting events, interfere with the rights of others with their actions. Within this article, we will present the powers of the Slovenian police aimed to ensure human rights and freedoms to all the individuals attending various sporting events. In doing so, we will particularly focus on the powers that are aimed directly against the perpetrators of various improper actions and wrongdoings, in the context of sporting events.

Since the right to security is considered a fundamental human right under the Constitution of the Republic of Slovenia (Official Gazette of the Republic of Slovenia, No. 33/1991 with amendments and changes, hereinafter: the URS), in order to ensure the safety to individuals and communities, the state must, by its actions, provide this fundamental right to all of its peoples (citizens and other persons under its territory), thus providing peace and order in the community. Peace and order, people working and creating in peaceful conditions is what makes the main core of the right to security. In times of peace it is the police that have the highest powers to attain security. Police attains security to protect significant social values and interests. The public interest is any situation related to deterring a threat that jeopardizes an individual, indeterminate group of persons or communities (Žaberl, 2015).

The worldwide awareness of importance of safety during sporting events has been prevalent for quite some time. Reducing security in all contexts has in the past led to various tragic events that have resulted in many fatalities or people sustaining physical injuries. In order to prevent violence at sporting events, "an important milestone was presented in the European Convention on Spectator Violence and Misbehavior at Sports Events and in particular at Football Matches" from 1985 (Official Gazette of SFRY, August 10, 1990) - MP, No. 14-34 /1990). It set out the measures that need to be 
implemented by various actors involved in ensuring safety at sporting events, primarily the football matches. The emphasis was on the importance of exchanging information and cooperation between police forces, promotion of the role of clubs in regulating and solving the problems of violence, the need for appropriate architectural solutions aimed at preventing of violence at stadiums, the identification of rowdy spectators, etc. Ten years ago the Convention was replaced by 2014 Council of Europe Convention on an Integrated Safety, Security and Service Approach at Football Matches and Other Sports Events, which is still in the process of ratification in Slovenia. In 2018, the Ministry of the Interior proposed to the Government of the Republic of Slovenia to take into consideration the aforementioned Convention, since "over the past decade it has become increasingly evident that the contents of the 1985 Convention are inconsistent and no longer follow the needs of modern times and, in some respects, are even contrary to the approach and good practices established in recent years". This document highlights the need for mutual cooperation and facilitating integration of various entities responsible for ensuring safety during events and gatherings. In doing so, and in accordance with the Convention which represents a basic guide to handle this area, they adopt the so-called integrated and more institutional approach. The preamble itself emphasizes the importance of supporter groups and local communities in reducing of the security risks associated with sports events taking place in public. All institutions and actors involved in organizing such events, including city authorities, the police, local communities and companies, supporter groups, football clubs and national level associations and federations, are encouraged to take part - in particular in risk assessment processes and in the preparation of appropriate preventive measures. At the operational level, the Convention provides for intelligence gathering, risk assessment, proportional intervention to prevent risk of escalation, international police cooperation, the sanctioning of offenses at sporting events committed abroad, assessing the possibility of introducing a ban on travel for rowdy fans, etc. The Convention also clearly condemns discrimination and racism in sporting events" (Bučar-Ručman in Slokan, 2019 ${ }^{1}$ ).

\footnotetext{
${ }^{1}$ An article with a working title Security threats in the framework of public events in Slovenia, prepared by Bučar-Ručman Aleš and Slokan Simon and to be published in
} 
"Various documents of the European Union also address the issue of prevention of violence at sporting events. The White Paper on Sport (Commission of the European Communities, 2007) underlines that, when it comes to sporting events, violence occurs in various forms, and has been shifting from inside stadiums to outside, including urban areas. A special emphasis is given to promoting dialogue and exchange of best practices in existing cooperation frameworks to prevent and handle racism at sporting events. A similar perception of problems and solutions can be found in the 2011 Communication from the Commission to the European Parliament, the Council, the European Economic and Social Committee and the Committee of the Regions that first mention the problems of racism, xenophobia and intolerance in amateur sport. Violence and racism at sporting events have also been condemned by the European Parliament (2017) in its Resolution on Integrated Approach to Sport Policy: Good Governance, Accessibility and Integrity" (Bučar-Ručman and Slokan, 2019a).

\section{Methodological and terminological concept of the article}

This paper, used a qualitative method of analyzing data, regulatory arrangements and other written material referring to the field of analysis. In addition, we applied quantitative methods of statistical analysis, aimed at presenting the number of implemented measures granted by these powers, as well as actual cases of violations of the said provisions. This led to the conclusion stemming from the hypothesis that the police powers which relate to the imposing of measures against individuals involved in various wrongdoings at sporting events are appropriate.

Bearing in mind the importance of combating all forms of violence, there have been radical changes in recent years in Slovenia which, based on international acts, establish a security policy in this context. Furthermore, this article sets a narrative of police framework, that is, police powers aimed at reducing violence in the context of sporting events.

The basic normative legal act determining the powers of the Police in Slovenia is the Police Tasks and Powers Act (Official Gazette of the Republic of Slovenia, No. 15/2013, 23/2015 - amended, 
10/2017, hereinafter PTPA). Article 1 stipulates that "the police implement tasks and exercise powers under the provisions of this Act, in order to provide for enforcement of general tasks and duties of the police which include: maintaining of security to individuals and communities, ensuring respect for the human rights and fundamental freedoms and strengthening of the rule of law". At the same time, Žaberl (2015a) adds that the respect for the human rights and fundamental freedoms as a segment of the basic duties of the police and grounds for implementing tasks and exercising powers of the police, basically involves two things: (a) the police must act when the individual's human rights and fundamental freedoms, which fall within the legal framework of police work, are threatened or violated (positive police action); (b) the police must refrain from their own unlawful interference with human rights and fundamental freedoms, when there are no legal grounds for this (negative police action). Paragraph 3 of Article 1 of the PTPA, provides legal grounds for the implementation of police tasks and exercise of police powers, stating that "the police perform tasks and exercise powers to prevent and eliminate threats that pose a threat to the well-being...".

What is important is the awareness of the fact, as Žaberl explains (2015b), that "with every police power, there is usually interference with a certain human right or fundamental freedom, whereby the police power can only be defined by law, and not by the bylaw (Article 15 of the Constitution of Republic of Slovenia). The definition elaborated the fundamental meaning of the police power, which is in facilitating the performance of police tasks. It is also important to note that the police power represents a measure, by exercising a police power a police officer starts to take action against a natural person (in exceptional cases, also against a legal person who is the holder of certain other rights) which, for the person against whom the authorization is (lawfully) used, and for the person against whom the power is exercised, the basic starting point of the duty of subordination...". The PTPA itself details in the Article 3 that "a police power is defined by law as a measure enabling police officers to carry out police tasks, which generally interfere with human rights and fundamental freedoms, as well as other rights". In order to ensure higher professionalism of police officers, it is fundamental that police officers are acquainted with their powers, and rights and obligations. In order to understand police work, it would be good that citizens are 
acquainted with both police powers and police activities - not only in terms of exercising their rights under the circumstances when they consider that police conduct was unlawful and unprofessional. It is also so that, citizens involved in a particular case, when officer undertakes legitimate tasks, would not resist or encourage police to impose more severe actions. At the same time, it is necessary to bear in mind that an individual power can only be carried out under the conditions laid down in the law and in the manner prescribed by law, rulebook or other regulation defining the police powers. In that regard, it is necessary to respect and protect the human dignity, the rights and fundamental freedoms guaranteed by the Constitution, laws and other regulations. When exercising powers, no individual shall be subject to torture, inhuman or degrading treatment (Pozderec, 2012: 21).

In this article, we will focus on prohibition of participation in sporting events (Article 62 of the PTPA) and trip cancellation and interruption (Article 63 of the PTPA), the purpose of their adoption and how they are implemented in practice, and what are their effects. In this regard, it is important to recognize that when assessing measures or powers, it is always necessary to have in mind the context of the social environment in which these powers have been adopted, the cultural background, political and economic context of the state, etc. In our case, we will discuss the measures or powers of the Slovenian police, and in this context it is also necessary to evaluate and understand the measure thereof.

\section{Normative model of police powers in Slovenia}

PTPA is the basic normative legal act regulating the tasks and powers of the police (Article 1 of the PTPA). The tasks of the police are defined in Article 4 of the PTPA, which derive from their basic duties. Those tasks are listed as follows:

- $\quad$ to protect people's lives, personal safety and property;

- $\quad$ to prevent, detect and investigate criminal and minor offences, to detect and apprehend perpetrators of criminal and minor offences and other wanted or missing persons and to hand them over to the competent authorities, as well as to collect evidence and investigate circumstances that are important for the identifying of material gain from the proceeds of criminal and minor offences;

to maintain public order; 
to supervise and direct traffic on public roads and on unclassified roads currently in use for traffic;

- $\quad$ to conduct state border control;

- to perform tasks in connection with the movement and residence of foreigners;

- to protect particular persons, premises, buildings and the environs of such buildings and, unless otherwise provided by law, to protect particular jobs and classified information of public authorities;

- $\quad$ to perform tasks in the event of natural and other disasters;

- $\quad$ to carry out other tasks set out in this Act and other regulations according to the law (Article 4 of the PTPA).

It is evident that the basic tasks of the police are aimed towards the protection of life, personal safety and property of people and prevention, detection and investigation of criminal offenses and violations and their perpetrators. The police are obliged to carry out all these activities in the framework of all occurrences and events, including sport gatherings as well.

Police powers are defined by Article 33 of the PTPA, whereby it is necessary to emphasize that police powers are tasks which are defined by the law, thus enabling policemen to perform their duties. However, it should be clear that despite the fact that PTPA provides for police powers, other laws also include the powers of police officers in relation to the performance of police tasks (for example, the Criminal Procedure Code, the Misdemeanors Act, etc.). Police powers must be determined by law (Nunič, 2015). Slovenian police officers are, thus, entrusted with the following powers:

- collect information,

- summon,

- issue warnings,

- issue instructions,

- identify persons and carry out the identification procedures,

- issue search warrants,

- carry out covert and specific control,

- provide photo identification,

- prepare photo robot images,

- carry out polygraphic procedures,

- establish roadblocks with checkpoints,

- use other modes of transport, communication or other means, 
- carry out security checks,

- carry out identity checks,

- access other peoples apartments and other facilities,

- seize objects,

- carry out counter-terrorism inspections,

- temporarily restrict the movement of persons,

- apprehend persons,

- prohibit the approach to a particular person, place or area,

- prohibit participation in sporting events,

- cancel and interrupt trips,

- detain persons,

- use coercive measures,

- perform security checks on persons,

- carry out accreditation procedure,

- exercise police powers on waterways,

- collect and process data and

- exercise other police powers specified in the laws (Article 33 of the PTPA).

It is obvious that the police have a number of authorizations enabling them to successfully perform their tasks. In the field of prevention of violence at sporting events, two directly target this issue: prohibition of participation in sporting events and trip cancellation and interruption.

\section{Prohibition of participation in sporting events (Article 62 of the PTPA)}

In this section, we will present police powers which address measures against an individual who was previously involved in violence at sporting events or in relation to them, and was imposed the said measure by the police. It is specified by the following:

- Paragraph 1 of Article 62 of the PTPA

If during a sports event or in connection with a sports event as provided by the act governing sport (hereinafter: sports events) a person has been caught committing an act that involves a breach of public order and peace with elements of violence or a minor offence under the act governing public gatherings, or an act that includes elements of a criminal offence with elements of violence, and if it is, in view of the circumstances, likely that he will proceed with the 
commission of such acts, police officers may impose on the person in question a measure prohibiting him from attending sports events for a one-year period. The anticipated circumstances related to the continuation of such conduct shall be substantiated in particular on the basis of the specific conduct of the person in connection with his previous conduct demonstrating elements of violence.

In that regard, Senčar (2015) adds a professional commentary ${ }^{2}$.

- Paragraph 2 of Article 62 of PTPA

After having dealt with the act including elements of a minor or criminal offence referred to in the preceding paragraph and under the circumstances justifying the imposition of the relevant measure, police officers shall, by issuing an on-the-spot verbal order, impose on the person in question a measure prohibiting him from attending sports events. They may also take his photograph. Within a deadline that may not exceed 24 hours, police officers shall also serve a written order on the person. The written order shall contain information on the person against whom the measure has been ordered (name, personal registration number or, for a foreign person, birth details, nationality and permanent or temporary place of residence), the measure ordered, the specification of circumstances justifying the imposition of the measure and a statement that the order will be sent for judicial review ex officio. Police officers shall call upon the person to provide them with the address at which the written order can be served on him. If police officers do not find the person at the address given or if he refuses to provide the address, they shall serve the order on him by affixing it to the bulletin board of the competent police station, to which the offender's special attention shall be drawn upon being issued a verbal order by police officers.

In that regard, Senčar (2015a) adds a professional commentary ${ }^{3}$.

- Paragraph 3 of Article 62 of PTPA

A person on whom a measure prohibiting him from attending sports events was imposed shall immediately leave the venue of the sports event. If the person does not comply with the order, police officers shall remove him from the venue.

\footnotetext{
${ }^{2}$ Senčar, A. (2015). Expert commentary on the Tasks and Powers of the Police Act, Ljubljana

${ }^{3}$ Senčar, A. (2015). Expert commentary on the Tasks and Powers of the Police Act, Ljubljana
} 
In this context, it is stipulated that an individual who has been imposed a measure of prohibition of participation in a sporting event must leave the venue immediately. In case it fails to obey the police order, police officers shall remove such a person from the venue, and may also use other legislative powers.

- Paragraph 4 of Article 62 of PTPA

Within 48 hours of issuing the order referred to in paragraph two of this Article, the police shall send it for review to the district court examining magistrate, who may uphold or, if the circumstances of the case show that conditions for issuing the order have not been fulfilled, annul the order. The examining magistrate shall decide on the measure no later than within 15 days. An appeal against the decision of the investigating judge may be filed with the non-trial panel of the district court within eight days; the panel shall decide on the appeal within 15 days of its receipt. Such appeal against the investigating judge's decision shall not stay its execution.

Based on legal grounds (ex lege), police officers are obliged to send every pronounced measure to the district court examining magistrate. In this case, it is about ensuring the legal protection of every individual, so that police officers may not abuse the delegated powers, and in case when prevailing conditions for imposing of the said measure have not appropriate.

- Paragraph 5 of Article 62 of the PTPA

A police officer shall direct an order to a person who fails to comply with the pronounced measure referred to in the first paragraph of this Article, to leave the sporting venue without any further delay. However, if the person continues infringement, police officers shall detain him pursuant to the provisions of this Act until the sporting event is over and other participants leave the venue.

In case of an individual who fails to comply with the pronounced measure that he/she must leave the event, or an individual who shows up for a sporting event despite a valid measure imposed upon him/her, the police shall order immediate departure from the venue, and shall, in so doing, impose fines, as stipulated in the Article 162 paragraph 162 of the PTPA, in the amount ranging between 300 to 800 euros. Shall an individual fail to leave the venue, the police officers order detention measure, pursuant to the third indent of the first paragraph of Article 64 of this Act. In addition, the detention takes 
place for the duration of the sporting event, or the maximum of 12 hours.

\section{- Paragraph 6 of Article 62 of PTPA}

The examining magistrate may, on the proposal of the police, order a person who has at least twice infringed the measure referred to in paragraph one of this Article to report to the district police station responsible for the performance of police tasks in his place of residence at the beginning of certain sports events. In his order, the investigating judge shall specify sports events at the beginning of which the person in question is obliged to report to the police station. The measure of reporting to a police station may remain in force for the period of the application of the measure referred to in paragraph one of this Article. The procedure relating to the order on reporting to a police station shall mutatis mutandis be subject to the provisions of paragraphs two and four of this Article.

In that regard, Senčar (2015b) adds a professional commentary ${ }^{4}$.

In this context, it should be emphasized that one single measure of reporting to a police station is currently in force in Slovenia.

- Paragraph 7 of Article 62 of PTPA

A person who, owing to objective circumstances (e.g. health condition, extraordinary weather conditions, travelling abroad), cannot report to the district police station, shall immediately notify the police of the existence of such circumstances and submit appropriate evidence.

An individual who has been imposed a valid police measure in this regard, can move freely anywhere and at the time of the event, yet he/she still must report to the police station. In case that an individual cannot approach a competent police station due to objective circumstances (work, illness, travel abroad) at the time of the event, he/she must provide evidence proving the aforementioned objective circumstances. If person fails to do so, the officers shall fine him under the second indent of the fourth paragraph of Article 162 of the PTPA, in the amount from 300 to 800 Euros.

- 8 paragraph of the Article 62 of thePTPA

If the steward service at a sporting event is provided by an entity engaged in securing public gatherings pursuant to the act

\footnotetext{
${ }^{4}$ Senčar, A. (2015). Expert commentary on the Tasks and Powers of the Police Act, Ljubljana
} 
governing public gatherings, security staff shall, following the prior acquisition of personal data on people who are prohibited from entering the venue of a sports event from the police, check at the entrance to the sports event compliance with the measure imposed and prohibited attendance at sports events. In such cases, they shall prevent the person in question from entering the venue.

In that regard, Senčar (2015d) adds a professional commentary ${ }^{5}$.

The sanction or measure of prohibiting participation in sporting events is, in its contents, very similar to the restrain order, usually issued to adverse party to refrain from approaching a particular person, place or area, while it is necessary to emphasize that the otherwise mentioned provision is similarly structured. The judiciary rule is extensive, as it specifies all procedures in the slightest detail. Such a stance of the legislator is justified by the fear of an unprecedented interference with the human right to freedom of movement so, in the concrete case, the legislator clearly wanted to avoid disproportionate interference with the human rights by means of providing in-depth and detailed instructions.

At the time of implementation of the said provisions in the normative framework in Slovenia, some complaints have been issued in relation to actions of the police, but no complaints were as successful as the court, in all cases, complied with police proposals.

The effectiveness of police work and application of this sanction in practice were also influenced by the decision of the District Court in Ljubljana which, by its Decision number I Kpd 23859/2017, ruled that firing of a pyrotechnic article at a sporting event represents an illegal act constituting elements of violence, as it puts in danger the lives of a large number of peaceful sports fans. In the operative sense, the said decision contributed to the fact that, when imposing the measure of prohibition of participation in sporting events, police officers were more likely to explain the danger of using pyrotechnic articles and, consequently, this also meant increase in the actual number of measures imposed.

In the conclusion of the presentation of this power, it is important to bear in mind the key amendment to the provisions of

\footnotetext{
${ }^{5}$ Senčar, A. (2015). Expert commentary on the Tasks and Powers of the Police Act, Ljubljana
} 
Article 62 of the PTPA made in 2017. The above proposal was based on knowledge, experience and operational needs. The duration of the measure of prohibition on participation in the sporting event was extended from the period of one to the period of two years. Proponents followed the socialization of the environment of subcultural groups where it had been perceived that the longer absence of an individual from the group, it causes the attitude of the group in the sense that the individual is gradually singled out from the group's activities. It should be noted that most of the above mentioned measures were imposed on individuals belonging to organized support groups who, with their activities, most often present a safety risk at a sporting event. Removing individuals inclined to violence, the dynamics in the group are changing, even in the direction that the inappropriate behavior can (easily) be lessened.

\section{Trip cancellation or termination (Article 63 of the PTPA)}

In this part, we will present a police power which refers to measures against a group of three or more persons traveling to a sporting event and being involved in various forms of violence. The fact is that in the past it was perceived that individuals, prior to a trip or during the travel were involved in various forms of violence, violating public order and peace, or committing various criminal offenses, while the police did not have the power to prevent such individuals or groups from further travel or departure to the venue. For this reason, the legislator has adopted a norm that allows police officers, when the necessary conditions have been met, to impose the said measure. The article itself stipulates the following:

- Paragraph 1 of Article 63 of the PTPA

If a group consisting of three or more persons travels to a sports event and even before departure breaches public order at the place of departure or during the journey, and despite a warning and an order by police officers does not refrain from such conduct, police officers may order their travel to be interrupted, or may prohibit access to the venue of the sports event in order to prevent repetition of such breaches. 

commentary ${ }^{6}$.

In that regard, Senčar (2015d) adds a professional

- Paragraph 2 of Article 63 of PTPA

If, under the given circumstances, it can be concluded that there is an organized group of supporters, the police may also order the measure from the preceding paragraph, also in the case when the persons have with them or in the means of transport used for the travel to a sport venue, objects that are likely to be the means of assault, or used in causing major public order violation and jeopardize the general safety of other people and facilities.

This power authorizes police officers to impose the measure of trip cancellation and interruption of, insofar as the group is perceived as organized group of supporters which are also in the possession of items that could be used in the context of violating of public order and peace or imposing jeopardy to general security during the sporting event.

\section{- Paragraph 3 of Article 63 of PTPA}

If a group consisting of three or more persons travels to a sports event by a means of transportation, police officers may order their journey to be interrupted on the grounds referred to in the preceding paragraph by prohibiting the journey by the means of transportation in question from being continued towards the venue of the sports event.

- Paragraph 4 of Article 63 of PTPA

The interruption of travel or prohibition of access to the venue of a sports event shall be ordered by police officers verbally and shall remain in force until the sports event is over and the participants leave the venue. Police officers shall properly document the order imposed and the grounds for its imposition in accordance with paragraph one of Article 130 of this Act.

In that regard, Senčar (2015a) adds a professional commentary ${ }^{7}$.

The fundamental change and the novelty in the PTPA in 2017 happened with the addition of the second paragraph. The above paragraph was added primarily in order to increase the effectiveness of

\footnotetext{
${ }^{6}$ Senčar, A. (2015). Expert commentary on the Tasks and Powers of the Police Act, Ljubljana

${ }^{7}$ Senčar, A. (2015). Expert commentary to the Tasks and Powers of the Police Act, Ljubljana
} 
the police that is to facilitate the exercise of the mentioned police power. Thus, based on the aforementioned provisions, the police may carry out the said measure, even if they find in the means of transport the objects that are likely to be used as means of assault or could pose a serious threat to public order and general security of people or facilities (for example pyrotechnics, batons and various types of knives and daggers). In addition, it is important to realize that the act of seizure itself is not related to responsibility of the individual. In the past, cases were detected when several such items were found in the means of transport, but the police officers were unable to determine who they belonged to. Items would be taken away, and the people would be free to leave. The present solutions stipulate the reasons for the exercise of the specific police power in these cases. In such cases, these objects may be considered as means to preparatory acts that would seriously jeopardize public order, general security or property. Following the amendment of the said provision, only in 2017, the aforementioned measure was successfully implemented in handling three such cases, whereas the number of such cases in the past four years was only two.

\section{Statistical review of the measures imposed}

In this chapter, we will present data on the number of measures of prohibition of participation in sporting events and cancellation/termination of the trip taken in Slovenia due to various violations of legislation, provided under conditions as stipulated by the law. At the same time, we will also present identified violations of these measures.

\section{Imposition of measures under the Article 62 of the PTPA}

The table below shows the number of measures imposed pursuant to Article 62 of the PTPA, which were issued by police officers in the period from 2013 to 2017, or since this power came into force.

Table 1: Number of measures imposed pursuant to the Article 62, period 2013-2017

\begin{tabular}{|c|c|c|c|c|c|}
\hline PTPA & $\mathbf{2 0 1 3}$ & $\mathbf{2 0 1 4}$ & $\mathbf{2 0 1 5}$ & $\mathbf{2 0 1 6}$ & $\mathbf{2 0 1 7}$ \\
\hline Article 62 & 11 & 27 & 5 & 15 & 30 \\
\hline
\end{tabular}


TOTAL 11 27 5 15 30

Source: Annual police reports 2013-2017

The above table shows that most of the measures were imposed in 2017. It should be noted, however, that this was a groundbreaking year, as there was a change in legislation, including the Decision of the District Court in Ljubljana, issued under number I Kpd 23859/2017, which assessed the use of pyrotechnics as a major offense. This decision resulted in the practice that the police officers, when they detect the use of pyrotechnics, are more likely to sanction or pronounce a measure to the first-offenders caught violating the provisions of the PAA during the sporting event. Additionally, there were a number of measures which were pronounced in 2014. It should be noted, though, that it was during this year that there was a massive violation, i.e. an assault that was carried out on a bus full of foreign supporters, and following the investigation, a majority of perpetrators were identified and a specific measure was imposed upon them (Slokan, 2017).

\section{Imposition of measures under the Article 63 of the PTPA}

In this context, we present the number of measures of trip cancellation/termination that police officers can impose on a supporter group violating public order and peace, or being in possession of prohibited items before departing or traveling to the sports venue. However, the police have not implemented this measure so far, as we are recording only few violations occurring during the travels of supporters' groups, whereas in reality the related incidents are actually occurring at the sports venues.

Table 2: Number of measures imposed pursuant to the Article 63, period 2013-2017

\begin{tabular}{|c|c|c|c|c|c|}
\hline PTPA & $\mathbf{2 0 1 3}$ & $\mathbf{2 0 1 4}$ & $\mathbf{2 0 1 5}$ & $\mathbf{2 0 1 6}$ & $\mathbf{2 0 1 7}$ \\
\hline Article 63 & & 1 & & 1 & 1 \\
\hline TOTAL & & $\mathbf{1}$ & & $\mathbf{1}$ & $\mathbf{3}$ \\
\hline
\end{tabular}

Source: Annual police reports, 2013-2017

The table shows that the most of the mentioned measures were imposed in 2017, upon the change of legislation. This was actually achieved by the amendment to the second paragraph, which stipulates 
that preparatory acts or the possession of certain objects are sufficient for the police to use the said power. In the previous years, only two such measures have been imposed (Slokan, 2017a).

\section{Violations of Article 62 of the PTPA}

In this context, we will show the number of violations of the measures imposed pursuant to Article 62, which means that we will show the data on the number of persons who, in spite of the pronounced measure of prohibition of participation in a sporting event, still came to attend the match.

Table 3: Number of established violations of the Article 62, period 20132017

\begin{tabular}{|c|c|c|c|c|c|}
\hline PTPA & $\mathbf{2 0 1 3}$ & $\mathbf{2 0 1 4}$ & $\mathbf{2 0 1 5}$ & $\mathbf{2 0 1 6}$ & $\mathbf{2 0 1 7}$ \\
\hline Article 162 & 0 & 2 & 2 & 4 & 5 \\
\hline TOTAL & $\mathbf{0}$ & $\mathbf{2}$ & $\mathbf{2}$ & $\mathbf{4}$ & $\mathbf{5}$ \\
\hline
\end{tabular}

Source: Annual police reports, 2013-2017

The above table shows that the most serious violations of the measures imposed were established to occur in 2017, which is understandable given the fact that in the past years most of the measures were imposed in relation to the prohibition of participation in sporting events. In one case, the individual violated the prohibition measure for the second time, which resulted in a motion of the procedure of reporting to the police station.

\section{General comments on the imposition of measures}

In this chapter we presented statistical data relating to established violations and measures in the context of sporting events in Slovenia. In doing this, it is necessary to keep in mind that we have only presented data on violations of the lex specialis (Public Information Act) and imposed measures under the Police Tasks and Powers Act, which is the only law that directly imposes measures against supporters and sports fans. Supporters can, indirectly, participate in events related to the series of other violations that are not presented here and have a great and direct impact in terms of violence and feelings of reduced security of individuals. For this reason, we believe that in the context of data presented here, it is necessary to know that many violations in Slovenia are being discovered, but also 
that the violations in recent years are lessened due to the changed legislation that introduced new measures against individual persons. However, it is essential that the said normative solutions are also being implemented (Slokan, 2017b).

\section{Conclusion}

The powers which refer to the prohibition of participation in a sporting event and the trip cancellation/termination or interruption are security measures used by the Slovenian police officers to reduce the various forms of violence in sporting events. Awareness of the rights and duties of every individual who participates in a sporting event is essential for the safety of the event itself. Police, as a body which has to permanently take care of safety, is obliged to remove the individual or groups wanting to undermine and jeopardize overall security due to various reasons. Naturally, they can do this only by means of powers or measures granted by the state with its legal norms.

It is unreasonable to believe that, since in Slovenia one violation of peace and order occurs in every 20 sporting events, that therefore this is acceptable. Everyone has the right to attend an event, whatever the role, and that he/she enjoys the same rights that no one should be allowed to jeopardize.

The powers that were presented in the context of the wider eurozone, where certain countries recognize a huge number of different measures and powers of the police, aimed at prevention and suppression of violence in sporting events, may, in the end, not mean much. However, as it was emphasized at the beginning, it is necessary to take into account the cultural, sociological, political and security environment of Slovenia. In this context, we can say that serious cases of mass violations in Slovenia rarely occur at public gatherings. Regardless of that, the police always undertake various activities to identify and sanction the individual who violates certain provisions of the law. Regarding the number of measures imposed pursuant to Articles 62 and 63 of PTPA, we can say that the given powers are appropriate and efficient in the context of Slovenian setting. Of course, this area is developing on a daily basis, both in the field of police powers and security, as well as in the area of greater assurance of the safety of the entities performing activities in the context of sporting events. 
All stakeholders who are in charge of safety at sporting events must bear in mind their roles and responsibilities. Only with joint efforts will the process of socializing of the particular setting lead to changes in the way society addresses violence and its reduction. Logically, this also leads to reduction in the need to use special police powers.

\section{List of references}

1. White Paper on Sport, European Commission, number IP/07/1066.

2. Bučar-Ručman, A. (2004). Violence and youngsters. Youth Cultural Center Club, Novo mesto.

3. Bučar-Ručman, A., Slokan, S. Security threats to public events in Slovenia - under preparation. The article will be published in 2019.

4. European Convention on Spectator Violence and Misbehavior at Sports Events and in particular at Football Matches, 1985, The Official Gazette of the Socialist Federal Republic of Yugoslavia, No. 14-34/1990.

5. The Council of Europe Convention on Integrated Safety, Security, and Service Approach at Football Matches and Other Sports Events, 2014. On 16 October 2017 the Government of the Republic of Slovenia supported the ratification of the decision no. 500-257/2015/10.

6. Annual activity report of police, 2015, Ministry of the Interior, Police.

7. Annual activity report of police, 2016, Ministry of the Interior, Police.

8. Annual activity report of police, 2017, Ministry of the Interior, Police.

9. Nunić, M. (2015). Expert commentary to the Tasks and Powers of the Police Act, Ljubljana.

10. Annual activity report of police, 2013, Ministry of the Interior, Police.

11. Annual activity report of police, 2014, Ministry of the Interior, Police. 
12. Pozderec, F. (2012). Protection of human rights and fundamental freedoms in police procedures, doctoral thesis. University of Ljubljana, Faculty of Management, Ljubljana.

13. European Parliament resolution of 2 February 2017 on an integrated approach to Sport Policy: good governance, accessibility and integrity 2016/2143 (INI).

14. Senčar, A. (2015). Expert commentary on the Tasks and Powers of the Police Act, Ljubljana.

15. Order of the District Court in Ljubljana, number I Kpd 23859/2017, 3. 8. 2017

16. Slokan, S. (2017). Violence during sports events - prevention of violence in Slovenia, Publication »Security and sport: regional experiences and perspectives: collection of papers", Football Association of Republika Srpska and the Ministry of the Interior of Republika Srpska, Banja Luka, pages 75-94.

17. Constitution of the Republic of Slovenia, The Official Gazette of Republic of Slovenia numbers33/1991,42/1997 - UZS68, 66/2000 UZ80, 24/2003 - UZ3a, 47, 68, 69/2004 - UZ14, 69/2004 - UZ43, 69/2004 - UZ50, 68/2006 - UZ121,140,143, 47/2013, 47/2013, 75/2016 - UZ70a.

18. Public Assembly Act, The Official Gazette of Republic of Slovenia, No. 59/2002, 60/2005 - ZJA-A, 90/2005, 85/2009, 59/2010, $39 / 2011$.

19. Police Tasks and Powers Act, The Official Gazette of Republic of Slovenia, No. 15/2013, 23/2015 - amended, 10/2017.

20. Public Roads Act, The Official Gazette of Republic of Slovenia, No. 109/2010, 57/2012, 63/2013, 68/2016, 54/2017, 3/2018 Decision US.

21. Misdemeanor Act, The Official Gazette of Republic of Slovenia, No. 7/2003, 86/2004, 7/2005 - skl. US, 34/2005 - DecisionUS, 44/2005, 40/2006, 51/2006 amended, 115/2006, 139/2006 - odl. US, 17/2008, 21/2008 - amended76/2008 - ZIKS-1C, 109/2009 odl. US, 108/2009, 45/2010 - ZintPK, 9/2011, 21/2013, 111/2013, 74/2014 - Decision US, 92/2014 - odl. US, 32/2016, 15/2017 odl. US, 27/2017-Zpro.

22. Protection of Public Order Act, The Official Gazette of Republic of Slovenia, No. 70/2006.

23. Private Security Act, The Official Gazette of Republic of Slovenia, No. $17 / 2011$. 
24. Žaberl, M. (2015). Expert commentary to the Tasks and Powers of the Police Act, Ljubljana.

\section{Забрана учествовања у спортским догађајима и прекид путовања - полицијска овлашћења у Републици Словенији као средства за смањење насиља на спортским догађајима}

Сажсетак: Циљ овог рада је представљање полицијских овлашћењ у у Словенији, са фокусом на овлашћења која су директно усмерена на смањење насиља на спортским догађајима. Последьих година, како у свету, тако и у Словенији, сведочи смо повећања различитих облика насиља током различитих спортских догађаја, који посредно или непосредно угрожавају општу безбедност. На основу овог сценарија и на основу различитих подзаконских аката, Словенија је усвојила низ мера усмерених на спречавање и сузбијағе различитих облика насиља током спортских догаЂаја. У 2013. години полицијским службениима су, између осталог, додељена још два овлашћења - забрана учешћа на спортским догађајима и отказивање и прекид путовања.

Намена овог рада је да презентује сва овлашћења словеначке полищије, стављајући нагласак на полицијска овлашћења која имају за ичиь спречавање насиља на спортским догађајима. ТакоЂе, намјена му је да покаже број изрешених мера и откривених кршења ових овлашћења. Поред тога, овај рад представља квалитативни метод анализе података и / или нормативних решена $и$ других писаних материјала релевантних за процес анализе. Ово такође укључује и квантитативни метод статистичке анализе, којим се приказују стварни подаци.

Сам садржај је актуелан у смислу познаваға полищијских овлашћења и важности свестио одговорности у вези са превенцијом насиља на спортским догађајима.

Кључне речи: полищија, поличијска овлашћења, забрана учествовањ у спортским догађајима, прекид путовања, насиље. 